\title{
UPAYA MENINGKATKAN AKTIVITAS DAN KEMAMPUAN BERPIKIR KREATIF MATEMATIK DENGAN PENDEKATAN PAIKEM BERBANTUAN CD PEMBELAJARAN MATERI SEGITIGA BAGI PESERTA DIDIK KELAS VIIB SMP 2 JIKEN TAHUN PELAJARAN 2009/2010
}

\author{
0leh:Isna Purti Astuti
}

\begin{abstract}
ABSTRAK
Upaya Meningkatan Aktivitas dan Kemampuan Berpikir Kreatif Matematik dengan Pendekatan Paikem berbantuanCD Pembelajaran materi Segitiga bagi Peserta Didik kelas VIIB SMP 2 Jiken Tahun pelajaran 2009/2010 merupakan penelitian tindakan kelas yang memiliki tujuan untuk meningkatkan aktivitas dan kemampuan berpikir kreatif matematik. Penelitian ini dilakukan 2 siklus, dimulai dengan perencanaan yang terdiri dari apresepsi, kegiatan inti dan penutup, kemudian dilanjutkan dengan pelaksanaan tindakan, pengamatan dengan lembar observasi dan refeksi dengan membandingkan hasil tes kemempuan berpikir kreatif matematikdari kondisi awal ke siklus 1 dan dari siklus 1 ke siklus 2 .

Berdasar analisis data dari kondisi awal ke siklus I mengalami peningkatan 21,88\%, antusias dan perhatian peserta didik meningkat, peserta didik yang pasif berkurang, dari siklus I ke siklus II juga terjadi peningkatan 21,88\%, dengan antusias peserta didik lebih meningkat. Berdasar hasil penelitian terlihat dari kondisi awal ke siklus II mengalami peningkatan $43,76 \%$, proses belajar mengajar meningkat karena peserta didik lebih aktif, antusias,serta perhatian peserta didik lebih meningkat. Respon peserta didik dalam pembelajaran juga menunjukkan hasil baik lebih dari $75 \%$.
\end{abstract}

\section{Kata kunci : Aktivitas, kemampuan berpikir kreatif matematik, pendekatan PAIKEM}

\section{LATAR BELAKANG}

$\begin{array}{ccr}\text { Salah satu } & \text { materi } & \text { dalam } \\ \text { matematika yang } & \text { memiliki tingkat }\end{array}$ keabstrakan tinggi adalah geometri. Menurut Aydin, Hallat, dan Jakubowski (2007:1) selama beberapa dekade, banyak peserta didik yang mengalami kesulitan dalam pembelajaran geometri baik pada sekolah menengah maupun perguruan tinggi. Kendala tersebut melahirkan kegagalan pada peserta didik, hal ini bisa terjadi antara lain karena peserta didik kurang aktvitas, tidak dapat menangkap konsep dengan benar, peserta didik tidak menangkap arti dari lambang-lambang, peserta didik tidak memahami asal usulnya suatu prinsip, pengetahuan peserta didik tidak lengkap.

Pembelajaran geometri materi Segitiga yang berlangsung di SMP 2 Jiken Blora untuk materi segitiga, kegiatan pembelajaran masih terpusat pada pendidik, peserta didik cenderung pasif, kurang antusias dan beraktivitas dalam pembelajaran. Kreativitas perorangan maupun berkelompok dapat dikatakan rendah terbukti setiap ulangan dalam bentuk soal yang bervariasi, peserta didik tidak bisa mengerjakan sama sekali, mereka tidak memiliki cara atau jawaban lain selain sesuai contoh, mereka selalu menggantungkan jawaban dari teman yang pandai di kelas tersebut, bahkan melalui tes kemampuan berpikir kreatif hasilnya juga tidak kreatif.

Agar pembelajaran geometri menjadi pembelajaran yang menyenangkan (joyfull learning), tidak membosankan, diperlukan pendekatan yang bisa mencoba meminimalkan kendala dan mengoptimalkan potensi, dalam aplikasinya seorang pendidik mencoba menciptakan pengajaran yang berkesan, dengan berusaha mengurangi sifat abstrak tersebut sehingga memudahkan peserta didik menangkap materi yang diberikan, dan menyelenggarakan pembelajaran yang mampu mengundang partisipasi aktif peserta didik, pembelajaran yang bisa menumbuhkan kreativitas dalam upaya mencapai tujuan Pendidikan Nasional.

Pendekatan PAIKEM, merupakan salah satu pendekatan dalam pembelajaran yang memfokuskan kepada peserta didik dalam hal memberikan pengalaman belajar 
untuk meminimalkan kendala dan mengoptimalkan potensi sehingga memperoleh kemampuan pemecahan masalah, berpikir kreatif, pengembangan ketrampilan-ketrampilan belajar yang lain (Joyoatmojo 2009:12) dan CD (compact disk) pembelajaran merupakan salah satu sumber belajar yang dirancang (learning resources by design) karena mampu menampilkan efek suara, gambar dan gerak, sehingga pesan yang kita sampaikan lebih hidup, menarik, dan kongkret, serta dapat memberi kesan seolah-olah peserta didik terlibat dalam pengalaman belajar tersebut.

\section{RUMUSAN MASALAH}

Apakah dengan pendekatan PAIKEM berbantuan $\mathrm{CD}$ pembelajaran dapat meningkatkan aktivitas dan kemampuan berpikir kreatif matematik materi segitiga bagi peserta didik kelas VIIB SMP 2 Jiken Tahun pelajaran 2009/2010?

\section{TUJUAN PENELITIAN}

1. Tujuan Umum, untuk meningkatkan aktivitas dan kemampuan berpikir kreatif matematik materi segitiga.

2. Tujuan Khusus, untuk meningkatkan aktivitas dan kemampuan berpikir kreatif matematik materi segitiga dengan pendekatan PAIKEM bagi kelas VIIB SMP 2 Jiken Blora tahun pelajaran 2009/2010

\section{MANFAAT PENELITIAN}

1. Peserta didik (a) Terciptanya suasana pembelajaran yang dapat meningkatkan aktivitas peserta didik sehingga dapat menumbuhkan kemampuan berpikir kreatif matematik, (b) Dapat menumbuhkan sikap bekerjasama dengan orang lain, (c) Dapat melatih peserta didik berkreativitas dalam mengungkapkan ide sendiri, (d) Hasil belajar berupa tes kemampuan berpikir kreatif matematik peserta didik dapat meningkat.

2. Pendidik (a) Memperluas wawasan pendidik matematika tentang perangkat pembelajaran yaitu tes kemampuan berpikir kreatif matematik, (b) Motivasi dalam meningkatkan kemampuan yang bervariasi sehingga dapat memperbaiki sistem pembelajaran dengan memberikan layanan yang terbaik bagi peserta didik

3. Sekolah (a) Dapat memberi sumbangan yang baik untuk sekolah dalam rangka perbaikan proses pembelajaran untuk peningkatan mutu sekolah, (b) Sebagai referensi bagi para peneliti dalam bidang pembelajaran matematika.

\section{LANDASAN TEORI}

\section{Pendekatan PAIKEM}

PAIKEM (Pembelajaran Aktif, Inovatif, Kreatif, Efektif dan Menyenangkan) merupakan salah satu model pembelajaran yang baru dikembangkan di Indonesia. Konsep pembelajaran dengan pendekatan PAIKEM bertujuan untuk menciptakan suatu lingkungan belajar yang lebih melengkapi peserta didik dengan keterampilanketerampilan, pengetahuan dan sikap bagi kehidupan kelak.

PAIKEM adalah Pembelajaran yang menunjukkan pada proses yang menempatkan peserta didik sebagai center performance. Aktif diartikan peserta didik maupun berinteraksi untuk menunjang pembelajaran. Active learning bisa dibangun oleh seorang pendidik yang bertanggung jawab, motivator yang bijak, berpikir positif, terbuka pada ide baru dan saran dari peserta didik atau orang tuanya/masyarakat memahami kebutuhan peserta didik secara individual, dan mengikuti perkembangan pengetahuan. Inovatif dimaksudkan dalam proses pembelajaran muncul ide-ide baru atau inovasi positif yang lebih baik. Kreatif lebih sering dikaitkan dengan seni daripada matematika (Bolden et al 2009:12). Kreativitas artinya daya cipta. Untuk menggali konsepsi kreativitas dalam mengajar matematika diartikan pendidik memberikan variasi dalam kegiatan belajar mengajar dan membuat alat bantu belajar, bahkan mencipta teknik-teknik mengajar tertentu sesuai dengan tingkat kemampuan peserta didik dan tujuan belajarnya. Peserta didik akan kreatif, bila diberi kesempatan merancang/membuat sesuatu, menuliskan ide atau gagasan. Efektif yang diartikan sebagai ketercapaian suatu tujuan (kompetensi) merupakan pijakan utama suatu rancangan pembelajaran. Menyenangkan diartikan sebagai suasana belajar mengajar yang "hidup", semarak, terkondisi untuk terus berlanjut, ekspresif, dan mendorong pemusatan perhatian peserta didik terhadap belajar.

Berdasarkan uraian di atas, maka dapat disimpulkan bahwa PAIKEM adalah 
proses belajar dimana pendidik harus menciptakan suasana pembelajaran sedemikian rupa sehingga peserta didik aktif bertanya, mempertanyakan, mengemukakan gagasan, kreatif, kritis serta mencurahkan perhatian/ konsentrasinya secara penuh dalam belajar serta suasana pembelajaran yang menimbulkan kenyamanan bagi peserta didik untuk belajar. Secara garis besar, PAIKEM dapat digambarkan sbb:

\begin{tabular}{|c|l|}
\hline Komponen & \multicolumn{1}{c|}{ Dalam Pembelajaran } \\
\hline Pendidik & $\begin{array}{c}\text { Kegiatan } \\
\text { Sebagai fasilitator, menggunakan berbagai alat bantu dan berbagai cara } \\
\text { dalam membangkitkan semangat belajar, menerapkan cara mengajar yang } \\
\text { lebih kooperatif dan interaktif termasuk cara belajar kelompok, } \\
\text { menerapkan berbagai strategi / model pembelajaran, memotivasi peserta } \\
\text { didik melalui kegiatan yang menantang kemampuan peserta didik untuk } \\
\text { berpikir kreatif, kritis dan mampu memecahkan masalah, Menggunakan } \\
\text { berbagai macam strategi mengajar termasuk pembelajaran yang lebih } \\
\text { interaktif dalam kelompok serta lebih banyak praktek. }\end{array}$ \\
\hline Peserta didik & $\begin{array}{l}\text { Lebih mendominasi dan mewarnai pembelajaran, Terlibat dalam berbagai } \\
\text { kegiatan yang mengembangkan pemahaman dan kemampuan mereka } \\
\text { dengan penekanan pada belajar berbuat (learning by doing), giat dan } \\
\text { dinamis mengikuti pelajaran, secara fisik dan mental aktif ditandai dengan } \\
\text { tercurahnya konsentrasi yang tinggi, berani mengemukakan pendapat, tidak } \\
\text { malu terlibat dalam kegiatan }\end{array}$ \\
\hline Lingkungan \\
kelas & $\begin{array}{l}\text { Pendidik mengatur lingkungan kelas dengan cara memajang buku-buku } \\
\text { dan bahan belajar yang menarik, menyediakan pojok untuk membaca, hasil } \\
\text { karya peserta didik dipajang di kelas, kelas dibuat semenarik mungkin, } \\
\text { lingkungan digunakan sebagai sumber belajar, tata letak formasi kelas } \\
\text { diubah dan disesuaikan dengan kegiatan. }\end{array}$ \\
\hline
\end{tabular}

( Indrawati dan Setiawan 2009:17)

2. INDIKATOR DAN PRINSIP proses belajar mengajar dilaksanakan.

\section{PENERAPAN PAIKEM}

Penerapan pendekatan PAIKEM

oleh pendidik bisa dicermati dengan

berbagai indikasi yang muncul pada saat
Kriteria ada atau tidaknya pembelajaran aktif, inovatif, kreatif, dan menyenangkan diantara dapat dilihat dari beberapa indikator sebagai berikut.

\begin{tabular}{|l|l|l|}
\hline \multicolumn{1}{|c|}{ Indikator Proses } & \multicolumn{1}{|c|}{ Penjelasan } & \multicolumn{1}{c|}{ Metode } \\
\hline $\begin{array}{l}\text { 1. Pekerjaan peserta didik } \\
\text { (diungkapkan dengan } \\
\text { bahasa/kata-kata peserta didik } \\
\text { sendiri) }\end{array}$ & $\begin{array}{l}\text { PAIKEM mengutamakan } \\
\text { peserta didik agar mampu } \\
\text { berfikir berkata dan } \\
\text { mengungkapkan sendiri. }\end{array}$ & $\begin{array}{l}\text { Pendidik membimbing dan } \\
\text { memajang hasil karyanya } \\
\text { agar dapat saling belajar. }\end{array}$ \\
\hline $\begin{array}{l}\text { 2. Kegiatan peserta didik diberi kesempatan untuk } \\
\text { mengalami,melakukan sendiri). }\end{array}$ & $\begin{array}{l}\text { Bila peserta didik } \\
\text { mengalami atau } \\
\text { mengerjakan sendiri } \\
\text { mereka belajar tentang apa } \\
\text { saja. }\end{array}$ & $\begin{array}{l}\text { Pendidik dan peserta didik } \\
\text { interaksif dan pekerjaan } \\
\text { peserta didik dipajang untuk } \\
\text { meningkatkan motivasi. }\end{array}$ \\
\hline $\begin{array}{l}\text { 3. Ruangan kelas } \\
\text { Penuh pajangan hasil karya } \\
\text { peserta didik dan alat peraga } \\
\text { sederhana buatan pendidik dan } \\
\text { peserta didik. }\end{array}$ & $\begin{array}{l}\text { kelas dan dari hasil } \\
\text { pajangan itu peserta didik } \\
\text { saling belajar. }\end{array}$ & $\begin{array}{l}\text { Pengamatan ruangan kelas } \\
\text { dan dilihat apa saja yang } \\
\text { dibutuhkan untuk dipajang. }\end{array}$ \\
\hline $\begin{array}{l}\text { 4. Penataan meja kursi } \\
\text { (meja kursi tempat belajar diatur } \\
\text { secara fleksibel). }\end{array}$ & $\begin{array}{l}\text { Pendidik melaksanakan } \\
\text { dengan berbagai setting } \\
\text { tempat duduk. }\end{array}$ & $\begin{array}{l}\text { Diskusi, kerja kelompok dan } \\
\text { pendekatan individual } \\
\text { pendidik kepada peserta didik } \\
\text { yang prestasinya kurang. }\end{array}$ \\
\hline
\end{tabular}




\begin{tabular}{|c|c|c|}
\hline $\begin{array}{l}\text { 5. Suasana bebas } \\
\text { Peserta didik memiliki dukungan } \\
\text { suasana bebas untuk } \\
\text { mengungkapkan pendapat }\end{array}$ & $\begin{array}{l}\text { Peserta didik dilatih untuk } \\
\text { mengungkapkan bebas } \\
\text { baik dalam diskusi, tulisan } \\
\text { maupun kegiatan lain }\end{array}$ & $\begin{array}{l}\text { Pendidik dan peserta didik } \\
\text { mendengarkan } \\
\text { menghargai pendapat peserta } \\
\text { didik lain }\end{array}$ \\
\hline $\begin{array}{l}\text { 6. Umpan balik pendidik } \\
\text { (pendidik memberi tugas yang } \\
\text { bervariasi dan secara langsung } \\
\text { memberi umpan balik agar } \\
\text { peserta didik memperbaiki } \\
\text { kesalahannya). }\end{array}$ & $\begin{array}{lr}\text { Pendidik } r \text { mendorong } \\
\text { peserta didik untuk } \\
\text { bereksplorasi, ran } \\
\text { memberi danbingan } \\
\text { individu dan kelompok. }\end{array}$ & $\begin{array}{l}\text { Penugasan individual dan } \\
\text { kelompok. }\end{array}$ \\
\hline $\begin{array}{l}\text { 7. Sudut baca } \\
\text { (sudut kelas sangat baik bila } \\
\text { diciptakan sebagai sudut baca } \\
\text { untuk peserta didik). }\end{array}$ & $\begin{array}{l}\text { Sudut baca di ruang kelas } \\
\text { akan mendorong peserta } \\
\text { didik untuk gemar } \\
\text { membaca. }\end{array}$ & $\begin{array}{l}\text { Observasi kelas, dan } \\
\text { pendekatan pada orang tua. }\end{array}$ \\
\hline $\begin{array}{l}\text { 8. Lingkungan sekitar } \\
\text { Lingkungan sekolah dijadikan } \\
\text { media pembelajaran. }\end{array}$ & $\begin{array}{l}\text { Sawah, lapangan dan lain- } \\
\text { lain dioptimalkan } \\
\text { pemanfaatannya untuk } \\
\text { media pembelajaran. }\end{array}$ & $\begin{array}{l}\text { Observasi lapangan, } \\
\text { eksplorasi, diskusi kelompok, } \\
\text { tugas individu da lain-lain. }\end{array}$ \\
\hline
\end{tabular}

3. Kemampuan Berpikir Kreatif tindakan kreatif dalam kajian matematika Munandar (1999:47) mendefinisikan kreativitas sebagai kemampuan untuk membuat kombinasi baru, berdasarkan data, informasi, atau unsur-unsur yang ada. Jadi Kreativitas merupakan gabungan (kombinasi) dari halhal yang sudah ada sebelumnya.

Kriteria kemampuan berpikir kreatif menurut Siswono (2007:1-2) adalah sebagai berikut.

1. Tingkat Berpikir Kreatif 4 (Sangat Kreatif), mampu menyelesaikan suatu masalah dengan lebih dari satu alternatif jawaban maupun cara penyelesaian.

2. Tingkat Berpikir Kreatif 3 (Kreatif), mampu menunjukkan suatu jawaban yang baru dengan cara penyelesaian yang berbeda (fleksibel)

3. Tingkat Berpikir Kreatif 2 (Cukup Kreatif), mampu membuat satu jawaban atau masalah yang berbeda dari kebiasaan umum.

4. Tingkat Berpikir Kreatif 1 (Kurang Kreatif), tidak mampu membuat jawaban atau membuat masalah yang berbeda (baru).

5. Tingkat Berpikir Kreatif 0 (Tidak Kreatif), tidak mampu membuat alternatif jawaban maupun cara penyelesaian..

Kreativitas seseorang dalam penelitian ini dapat dinilai dengan menggunakan alat evaluasi yang dikemukakan oleh Munandar yaitu empat meliputi kelancaran (fluency) menjawab, keluwesan (fleksibilitas), dan orisinalitas dalam berpikir matematik, serta kemampuan untuk mengelaborasi (mengembangkan, memperkaya, memperinci) suatu gagasan matematik.

\section{Aktivitas Peserta Didik dalam Pembelajaran}

Aktivitas digunakan dalam semua kegiatan mengajar, baik di dalam maupun di luar kelas. Hanya saja penggunaannya dilaksanakan dalam bentuk yang berlainlainan sesuai dengan tujuan yang hendak dicapai dan disesuaikan pula pada orientasi sekolah. Aktivitas peserta didik selama proses pembelajaran berlangsung sangat berpengaruh terhadap hasil belajar. (Sanjaya 2006:137). Aktivitas dalam pendekatan PAIKEM, merupakan salah satu dasar untuk menentukan tingkat keberhasilan belajar. Aktivitas disini adalah aktivitas yang dapat diamati karena aktivitas mereka harus menjadi salah satu point dalam penilaian dan dituangkan dalam lembar pengamatan.

\section{CD Pembelajaran sebagai Media}

Semua alat dapat dipandang sebagai media apabila digunakan untuk menyampaikan pesan atau informasi dengan tujuan pendidikan dan pengajaran. Salah satu bentuk multimedia yang merupakan kombinasi antara beberapa media teks, gambar, video dan suara sekaligus dalam 
satu tayangan tunggal adalah CD (compact disc). Kegiatan pembelajaran diarahkan untuk memperdayakan semua potensi peserta didik untuk menguasai kompetensi yang diharapkan (Majid 2008:24). Jadi CD pembelajaran adalah salah satu alat multimedia yang memuat materi pembelajaran dalam upaya memperdayakan semua potensi peserta didik untuk menguasai kompetensi yang diharapkan.

\section{KERANGKA BERPIKIR}

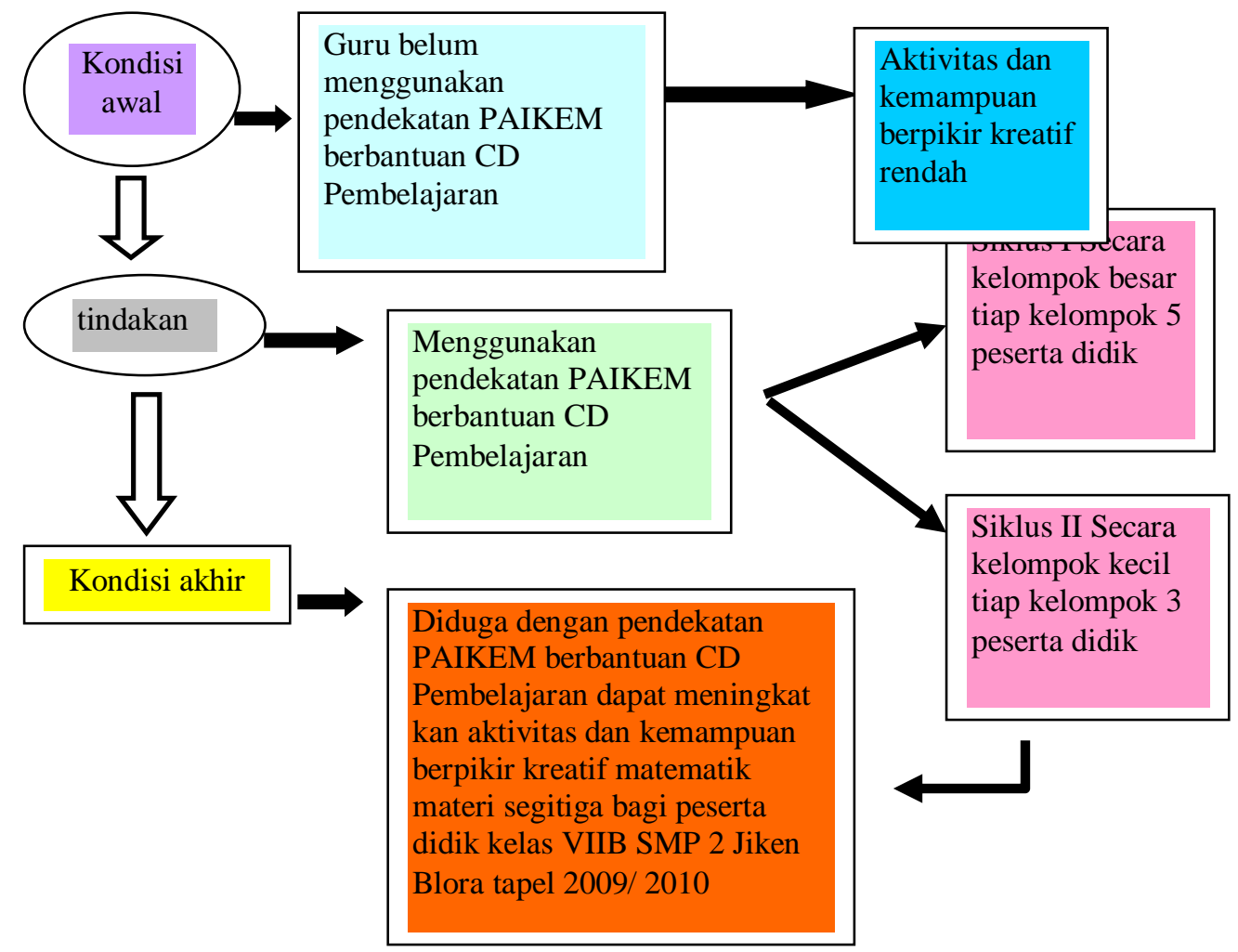

\section{Hipotesis}

Berdasarkan tinjauan pustaka dan kerangka berpikir yang telah dijabarkan diatas, dapat dimunculkan hipotesis penelitian sebagai berikut: dengan pendekatan PAIKEM berbantuan CD Pembelajaran materi segitiga dapat meningkatkan aktivitas dan kemampuan berpikir kreatif matematik bagi peserta didik kelas VIIB SMP 2 Jiken tahun pelajaran 2009/2010.

\section{METODOLOGI PENELITIAN}

Setting Penelitian dimulai dengan menyusun proposal pada bulan maret sampai dengan menyusun laporan bulan agustus 2010 dengan subyek penelitian adalah peserta didik kelasVIIB SMP 2 Jiken Blora tahun pelajaran 2009/2010 dengan jumlah 32 peserta didik

Sumber Data diperoleh dari (a) Pengamatan langsung dengan bantuan lembar observasi. Pengamatan ini digunakan untuk mengetahui keaktifan peserta didik dalam belajar, (b) Nilai tes kemampuan berpikir kreatif matematik sebanyak 3 kali yaitu kondisi awal, siklus I dan siklus II, (c) Respon peserta didik.Tehnik dan Alat pengumpulan data meliputi (a) Data keaktifan peserta didik dalam pembelajaran diambil melalui pengamatan yang dituangkan dalam lembar observasi, (b) Data kreativitas berasal dari tes kemampuan berpikir kreatif matematik, (c) data respon berasal dari lembar angket peserta didik.

Agar validitas teoritik terpenuhi maka diperlukan kisi-kisi butir soal untuk membuat soal supaya tidak terpusat, menyebar dan disesuaikan dengan kurikulum yang berlaku, sedangkan pemeriksaan data menggunakan trianggulasi dimaksudkan bahwa data atau informasi dari satu pihak harus dicek kebenarannya melalui sumber data yang berbeda untuk data yang sama atau sejenis. Analisis Data dengan analisis diskritif komparatif yaitu pada siklus I membandingkan nilai kondisi awal dengan nilai pada siklus I dan pada siklus II membandingkan hasil nilai pada siklus I dan 
hasil nilai siklus II, selain itu juga menganalisis data berdasarkan observasi yang dituangkan dalam kegiatan atau pelaksanaan pembelajaran.

\section{PROSEDUR PENELITAN}

Merupakan langkah-langkah yang harus dilalui oleh peneliti yang diawali dengan metode penelitian tindakan kelas dengan melakukan tindakan atau action. Prosedur penelitian meliputi perencanaan (planning), tindakan (acting), pengamatan (observing) dan refleksi (reflecting). Sebelum melaksanakan tindakan dalam proses pembelajaran, peneliti perlu menyiapkan berbagai macam persiapan antara lain: (1) Membuat RPP (2) Mempersiapkan sarana dan prasarana (3) Mempersiapkan lembar observasi, (4) Membuat tes kemampuan berpikir kreatif matematik, (5) Membuat lembar respon peserta didik dalam pembelajaran. Banyaknya tindakan yang dilakukan terdiri dari dua siklus dan setiap pelaksanaan siklus akan dievaluasi untuk mengetahui sejauh mana kemajuan yang diperoleh peserta didik dan kelemahan sehingga bisa ditentukan pada siklus berikutnya.

\section{Siklus I}

a. Planning atau perencanaan yang terdiri dari (1) Apersepsi, membentuk kelompok besar , (2) Kegiatan Inti, guru melaksanakan pendekatan PAIKEM(3) Penutup, diakhir pembelajaran dilakukan tes kemampuan berpikir kreatif matematik.

b. Pelaksanaan tindakan sesuai dengan perencanaan

c. Pengamatan /observing, peneliti melakukan pengamatan proses pembelajaran dari masing-masing kelompok besar yang dilakukan pada bulan Mei minggu ke-2 dan hasil yang diperoleh dari pengamatan tersebut adalah aktivitas dari peserta didik meningkat.

d. Refleksi adalah membandingkan hasil tes kemampuan berpikir kreatif matematik kondisi awal dengan kondisi setelah siklus I.untuk disimpulkan.

\section{Siklus II}

a. Planning atau perencanaan yang terdiri dari (1)Apersepsi, membentuk kelompok kecil (2) Kegiatan Inti, guru melaksanakan pendekatan PAIKEM, (3) Penutup, diakhir pembelajaran dilakukan tes kemampuan berpikir kreatif matematik. b. Pelaksanaan tindakan seperti perencanaan di atas.

c. Pengamatan /observing, peneliti melakukan pengamatan proses pembelajaran dari masing-masing kelompok kecil yang dilakukan pada bulan Mei minggu ke-3 dan hasil yang diperoleh dari pengamatan tersebut adalah aktivitas semakin meningkat.

d. Refleksi adalah membandingkan hasil tes kemampuan berpikir kreatif matematik kondisi setelah siklus I dengan kondisi setelah siklus II untuk disimpulkan.

\section{HASIL PENELITIAN DAN \\ PEMBAHASAN \\ 1.Diskripsi kondisi awal}

Aktivitas peserta didik dalam pembelajaran matematika sangat kurang, selain pembelajaran yang monoton, peserta didik menganggap bahwa matematika materi geometri itu adalah pelajaran yang sulit sehingga peserta didik sudah menyerah dulu sebelum mengetahui lebih dalam lagi. Dari 32 peserta hanya 8 orang yang menjawab tugas rumah ataupun latihan soal itu benar, peneliti sudah berusaha untuk memberikan contoh soal di dalam pembelajaran tetapi soal yang tidak sama contoh, peserta didik kebingungan dalam menjawabnya dan keaktifan mengikuti pembelajaran bisa dikatakan 10 peserta didik yang antusias mengikuti kegiatan tersebut.

Dari ungkapan tersebut di atas peneliti berupaya untuk mengatasi masalah tersebut dengan membuat kondisi pembelajaran sangat menarik sehingga bisa memotivasi peserta didik untuk belajar dan jika ada soal yang bervariasi peserta didik berusaha memperoleh jawaban itu sesuai dengan ide masing-masing peserta didik. Dengan CD pembelajaran yang diberikan mampu merangsang pembelajaran sehingga membuat peserta didik tertarik dan senang untuk mempelajari materi tersebut. Hal ini sesuai dengan fungsi dari media yaitu memberi semangat baru dan rasa senang mempelajari matematika (Samadhi 2007:46). Perangkat pembelajaran yang baru bagi peserta didik adalah tes kemampuan berpikir kreatif matematik. Mereka merasa tes tersebut adalah hal yang baru karena selama pembelajaran belum pernah mendapatkan tes yang seperti itu. Dua pertiga peserta didik di kelas VIIB menghadapi kesulitan dalam 
menyelesaikan soal yang memuat informasi tidak lengkap.

Ulangan dalam kondisi awal dapat dilihat bahwa nilai 3-5 ada 19 peserta didik dan nilai 6-8 ada 13 peserta didik dan 1 peserta didik dengan nilai di atas 8 dengan 21 peserta didik tidak kreatif, sehingga pada kondisi awal bisa dinyatakan dalam prosentase adalah $34,37 \%$

\section{Deskripsi Siklus 1}

a. Perencanaan kegiatan

1) Apersepsi, mengelompokkan peserta didik dalam kelompok besar yaitu tiap kelompok dengan 5 anggota

2) Kegiatan inti, dengan pendekatan PAIKEM berbantuan CD pembelajaran peserta didik lebih mendominasi dan mewarnai pembelajaran,

3) Penutup, untuk mengukur kreativitas dengan tes kemampuan berpikir kreatif matematik dengan 3 buah soal bentuk essay.

b. Pelaksanaan Kegiatan

Pada pelaksanaan kegiatan ini, pendidik melaksanakan kegiatan -kegiatan yang sesuai dengan perencanaan seperti tersebut di atas.

Hasil pengamatan

1) Proses belajar Aktivitas peserta didik sebagai salah satu dasar untuk menentukan tingkat keberhasilan dalam belajar atau aktivitas mereka harus memperoleh penghargaan atau menjadi salah satu poin dalam penilaian. Dari pengamatan peneliti terdapat 18 anak yang aktif, sedangkan yang lain hanya terdiam menunggu teman-temannya. Kontribusi aktivitas dapat meningkat lagi dengan seringnya pendidik memberi kesempatan sebesarbesarnya kepada peserta didik untuk mengutarakan pikiran atau pendapat sebuah ide tertentu, selain itu peserta didik juga diberi kesempatan untuk menuangkan imajinasinya dalam pembelajaran atau tindakan tertentu.

2) Hasil belajar Hasil belajar berupa tes kemampuan berpikir kreatif. Karena merupakan hal yang baru maka pada siklus I masih banyak peserta didik yang kurang kreatif. Dari 32 peserta didik yang tuntas kreatif ada 18 orang peserta didik.

\section{Deskripsi Siklus II}

a. Perencanaan kegiatan

1) Apersepsi, mengelompokkan peserta didik dalam kelompok besar yaitu tiap kelompok dengan 3 anggota.

2) Kegiatan inti, dengan pendekatan PAIKEM peserta didik terlibat dalam berbagai kegiatan yang mengembangkan pemahaman dan kemampuan mereka dengan penekanan pada belajar berbuat (learning by doing), giat dan dinamis mengikuti pelajaran, aktif ditandai dengan berani mengemukakan pendapat, tidak malu terlibat dalam kegiatan.

3) Penutup, untuk mengukur kreativitas dengan tes kemampuan berpikir kreatif matematik dengan 4 soal essay.

b. Pelaksanaan Kegiatan

Pada pelaksanaan kegiatan ini, pendidik melaksanakan kegiatan sesuai dengan perencanaan. Pendidik berupaya terus untuk memotivasi peserta didik untuk tidak takut mencoba dan berdiskusi dalam kerja kelompok dan sering menanyakan materi yang belum jelas. Respons peserta didik terhadap tugas yang diberikan pendidik juga semakin meningkat karena peserta didik semakin memiliki kepercayaan diri dalam menyelesaikan tugas yang diberikan Pendidik.

c. Hasil pengamatan

1) Proses belajar

Pada siklus II dari pengamatan peneliti terjadi peningkatan aktivitas dalam kelompoknya karena terdapat 25 anak yang aktif dalam pembelajaran dari 32 peserta didik. Kontribusi aktivitas dapat meningkat lagi dengan seringnya pendidik memberi kesempatan sebesarbesarnya kepada peserta didik untuk mengutarakan pikiran atau pendapat sebuah ide tertentu.

2) Hasil belajar 
Hasil belajar berupa tes kemampuan berpikir kreatif matematik. Dikatakan tuntas kreatif jika peserta didik tersebut mencapai nilai minimal 60. Dari 32 peserta didik terdapat 25 peserta didik yang tuntas kreatif sesuai kriteria indikator yang ditetapkan. d. Angket atau lembar respon diberikan setelah proses pembelajaran berlangsung dengan hasil menunjukkan lebih dari $75 \%$ peserta didik senang menggunakan $\mathrm{CD}$ pembelajaran sebagai media pembelajaran

\section{PEMBAHASAN/HASIL}

\section{PENELITIAN}

a. Pembahasan tindakan

\begin{tabular}{|l|l|l|}
\hline Kondisi awal & Siklus I & Siklus II \\
\hline Belum menggunakan & Sudah menggunakan & Sudah menggunakan \\
Pendekatan & Pendekatan PAIKEM berbantuan & Pendekatan PAIKEM \\
PAIKEM berbantuan & CD & berbantuan \\
CD pembelajaran & pembelajaran dengan kelompok & CD Pembelajaran \\
& besar & dengan kelompok kecil \\
& (a 3 5 orang ) & (a rang ) \\
\hline
\end{tabular}

b. .Pembahasan hasil pengamatan

\begin{tabular}{|l|l|l|}
\hline Aspek pengamatan & $\begin{array}{l}\text { Jumlah peserta didik yang aktif } \\
\text { (A) }\end{array}$ & $\begin{array}{l}\text { Jumlah peserta didik } \\
\text { yang kreatif(B) }\end{array}$ \\
\hline Siklus 1 & 18 & 18 \\
\hline Siklus 2 & 25 & 25 \\
\hline
\end{tabular}

Hasil penelitian siklus 1 ke siklus II

\begin{tabular}{|l|l|l|}
\hline Aspek pengamatan & $\begin{array}{l}\text { Jumlah \%peserta } \\
\text { didik aktif (A) }\end{array}$ & $\begin{array}{l}\text { Jumlah \% peserta } \\
\text { didik kreatif(B) }\end{array}$ \\
\hline Siklus 1 & 56,25 & 56,25 \\
\hline Siklus 2 & 78,13 & 78,13 \\
\hline Selisih $+/-$ & $+21,88$ & $+21,88$ \\
\hline
\end{tabular}

c. .Pembahasan refleksi

\begin{tabular}{|l|l|l|}
\hline Kondisi awal & \multicolumn{1}{|c|}{ Siklus I } & \multicolumn{1}{|c|}{ Siklus II } \\
\hline a.Hasil belajar & & \\
\hline$* 34,37 \%$ & $* 56,25 \%$ & $* 78,13 \%$ \\
\hline & $*$ meningkat 21,88\% & $*$ meningkat 21,88\% \\
\hline & (dari kondisi awal ke Siklus 1) & (dari siklus 1ke Siklus 2) \\
\hline & & $*$ meningkat 43,76\% \\
\hline bProses belajar & & (dari kondisi awal ke siklus 2) \\
\hline $34,37 \%$ & $56,25 \%$ & $78,13 \%$ \\
\hline & Meningkat 21,88\% & Meningkat 21,88\% \\
\hline & (dari kondisi awal ke siklus 1) & (dari siklus 1 ke siklus 2) \\
\hline & & Meningkat 43,76\% \\
\hline $\begin{array}{l}\text { Banyak peserta } \\
\text { didik yang }\end{array}$ & $\begin{array}{l}\text { Antusias dan } \\
\text { perhatian peserta didik meningkat, }\end{array}$ & $\begin{array}{l}\text { Antusias dan perhatian } \\
\text { peserta didik }\end{array}$ \\
\hline
\end{tabular}




\begin{tabular}{|l|l|l|}
\hline $\begin{array}{l}\text { kurang antusias, } \\
\text { pasif }\end{array}$ & peserta didik pasif berkurang & $\begin{array}{l}\text { lebih meningkat, } \\
\text { peserta didik nampak } \\
\text { aktif }\end{array}$ \\
\hline $\begin{array}{l}\text { *Dari lembar angket peserta didik menunjukkan lebih dari75\% } \\
\text { dengan pendekatan PAIKEM berbantuan CD pembelajaran. }\end{array}$ \\
\begin{tabular}{l} 
Respon peserta didik dalam pembelajaran hasilnya baik lebih dari 75\%. \\
\hline
\end{tabular} & $\begin{array}{l}\text { Proses belajar } \\
\text { mengajar meningkat }\end{array}$ \\
\hline
\end{tabular}

\section{Hasil Penelitian}

Dari data-data yang disajikan terlihat bahwa hasil belajar dari kondisi awal ke siklus II mengalami peningkatan $43,76 \%$ dan proses belajar mengajar meningkat $43,76 \%$ dari kondisi awal ke siklus II dengan melihat antusias dan perhatian peserta didik lebih meningkat, peserta didik nampak aktif sehingga dengan pendekatan PAIKEM berbantuan $\mathrm{CD}$ pembelajaran dapat meningkatkan aktivitas dan kemampuan berpikir kreatif matematik materi Segitiga .

\section{PENUTUP}

\section{Simpulan}

1. Secara Teori dan empirik Pendekatan PAIKEM berbantuan $C D$ pembelajaran dapat meningkatkan aktivitas dan kemampuan berpikir kreatif matematik materi Segitiga

2. Dari lembar angket peserta didik menunjukkan lebih dari75\% senang menggunakan

\section{DAFTAR PUSTAKA}

Aydin, E, Hallat, E dan Jakubowski, H. 2007. Reform-based Curriculum and Motivation in Geometry. Eurasia Journal of Mathematics, Science \& Technology Education, 4/3: 285-292.

Bolden, DS et al. 2009. Preservice primary teachers' conceptions of creativity in mathematics. Journal Education Studi Mathematic.

Indrawati dan Setiawan,W. 2009. Pembelajaran Aktif, Kreatif, Efektif, Menyenangkan bagi Guru $S D$. Bandung: P4TK IPA untuk program bermutu.

Joyoatmojo, S. 2009. Peningkatan Mutu Pendidikan Melalui Pakem makalah seminar nasional. Solo: IKA UNS.

Majid, A. 2008. Perencanaan Pembelajaran Mengembangkan standart kompetensi guru. Bandung: PT Remaja Rosda karya.

Munandar, U. 2009. Pengembangan Kreativitas Anak Berbakat. Jakarta: Rineka Cipta.

Sanjaya, W. 2006. Strategi Pembelajaran Berorientasi Standart Proses Pendidikan. Jakarta: Kencana.
CD pembelajatran sebagai media pembelajaran atau respon Peserta didik

\section{Saran-saran}

. Kreativitas dapat dikembangkan dengan didik untuk mengutarakan pikiran, pendapat atau ide penyelesaian dari soalsoal yang disajikan pendidik.

. Upaya meningkatkan kreativitas peserta pembelajaran selalu menyisipi soal-soal yang penyelesaiannya tidak tunggal, agar peserta didik dapat mengerjakan lebih dari satu cara penyelesaian dan peserta dengan soal bentuk tersebut. 
Samadhi, A. 2008 . pembelajaran aktif (active learning). Tersedia di http://eng.unri.ac.id/download/teachingimprovement/BK2_Teach\&Learn_1/ACtive\%20 Learning_5.PDF diakses 23 Nopember 2009.

Siswono, T.Y.E. 2007. Penjenjangan berpikir kreatif dan identifikasi tahap berpikir siswa dalam memecahkan dan mengajukan masalah matematika. Tersedia di http:// Falogyes, wordpress.Com/abstrak disertasi diakses 12 maret 2009.

\section{BIODATA}

Dra. ISNA PURTI ASTUTI M.Pd, Pendidikan S2 Prodi Pendidikan Dasar Konsentrasi Matematika PPs Unnes, lahir Di Blora 3 Pebruari 1969 bertugas sebagai Guru Matematika di SMP 2 Jiken Blora 